\title{
Improving Student Learning Outcomes Through Physics Learning Media Using Macromedia Flash
}

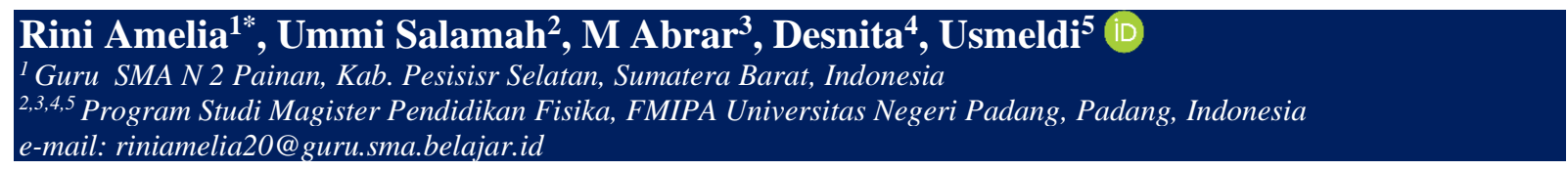

\section{A R T I C L E I N F O}

Article history:

Received June 04, 2021

Revised June 08, 2021

Accepted August 02, 2021

Available online August 25, 2021

Kata Kunci:

Macromedia Flash, Multimedi,

Hasil Belajar Fisika

Keywords:

Macromedia flash, Learning

Media, Physics Learning

Outcomes

DOI:

https://dx.doi.org/

10.23887/jet.v5i3.36203

\begin{abstract}
A B S T R A K
Dalam proses pembelajaran fisika, guru masih belum mampu mengembangkan media pembelajaran berbasis ICT menggunakan software macromedia flash yang efektif dan efisien. Perlu dilakukan analisis artikel dari hasil-hasil penelitian terdahulu untuk memahami media yang tepat untuk pembelajaran fisika. Penelitian ini dilakukan dengan tujuan untuk mengetahui jenis penelitian apa saja yang telah dilakukan dalam pengembangan media pembelajaran fisika mengunakan sofware macromedia flash dan untuk menganalisis effect size pengaruh media pembelajaran fisika mengunakan software macromedia flash ditinjau dari hasil belajar peserta didik berdasarkan tingkatan pendidikan, jenis media yang dikembangkan dan materi pembelajaran. Jenis penelitian yang digunakan adalah penelitian meta-analisis. Subjek penelitian ini yaitu 21 artikel tentang pengembangan media pembelajaran fisika mengunakan software macromedia flash ditinjau dari hasil belajar peserta didik yang telah diujicobakan di kelas terbitan tahun 2011-2020. Analisis data yang digunakan dalam penelitian ini adalah analisis kuantitatif dengan menghitung effect size menggunakan parameter statistik. Hasil penelitian yaitu efektivitas terbaik media pembelajaran fisika mengunakan software macromedia flash ditinjau dari hasil belajar peserta didik berdasarkan tingkatan pendidikan adalah pada Perguruan Tinggi. Efektivitas terbaik media ditinjau dari hasil belajar peserta didik berdasarkan jenis media yang dikembangkan adalah multimedia. Efektivitas terbaik media pembelajaran fisika ditinjau dari hasil belajar peserta didik berdasarkan materi pembelajaran adalah pada materi gerak. Dapat disimpulkan bahwa media pembelajaran yang menggunakan software macromedia flash merupakan media yang dapat membanti siswa dalam belajar.
\end{abstract}

\section{A B S T R A C T}

In the process of learning physics, teachers can still not develop ICT-based learning media using Macromedia flash software that is effective and efficient. It is necessary to analyze articles from the results of previous studies to understand the right media for learning physics. This research was conducted to know what types of research have been carried out in the development of physics learning media using Macromedia flash software and to analyze the effect size of the influence of physics learning media using Macromedia flash software in terms of student learning outcomes based on education level, type of media developed and learning materials. The type of research used is a meta-analysis study. The subjects of this research are 21 articles on the development of physics learning media using Macromedia flash software in terms of student learning outcomes that have been tested in class published in 2011-2020. The data used in this study is a quantitative analysis by calculating the effect size using statistical parameters. The result of the research is that the best effectiveness of physics learning media using Macromedia flash software in terms of student learning outcomes based on education level is in Higher Education. The best effectiveness of the media in terms of student learning outcomes based on the type of media developed is multimedia. The best effectiveness of physics learning media in student learning outcomes based on learning materials is on motion material. It can be concluded that Multimedia that uses Macromedia flash software is a medium that can help students in learning.

This is an open access article under the CC BY-SA license. Copyright $(2021$ by Author. Published by Universitas Pendidikan Ganesha.

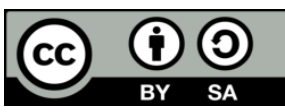

\section{INTRODUCTION}

The era of the industrial revolution 4.0 is synonymous with the rapid development of information and communication technology (ICT) (Chin \& Wang, 2021; Lange et al., 2020; Rajagukguk \& Simanjuntak, 2015). The development of ICT provides many conveniences and becomes a new way for humans to carry out activities (Heemskerk et al., 2012; Nursamsu \& Kusnafizal, 2017). For example, in sending money, just by pressing a few 
digits of the value of the money to be sent and a few digits of the destination account number, the money moves from one account to another. Advances in ICT have now provided a lot of convenience and comfort for human life, especially in education (Anwariningsih \& Ernawati, 2013; Lawrence \& Tar, 2018). One of the roles of ICT for education is the availability of facilities that can be used to carry out unidirectional or interactive learning. The use of ICT in education is proliferating. Therefore it requires updates to keep up with these developments (Arrosagaray et al., 2019; Baya'a et al., 2019). In updating following the development of ICT in the education process, teachers play an essential role because teachers are the main actors in education. Teachers must have the skills to utilize ICT in learning activities by developing interactive learning media (Arrosagaray et al., 2019; Baya'a et al., 2019; Kim et al., 2020).

Preliminary studies have been carried out in this study by analyzing several articles related to the development of physics learning media. Based on the initial study, it is found that the reality is different between ideal conditions and conditions in the field. The first actual condition is that students' learning achievement in physics subjects is still low compared to other subjects (Ariani, 2020; Gunawan et al., 2017; Saprudin et al., 2020). The second actual condition in the physics learning process is that most students seem less interested, less enthusiastic, and passive (Putri, I \& Sibuca, A, 2014; Rozi \& Kristari, 2020). The third actual condition is that not many teachers use ICT media. Even the lecture method is still quite popular in the learning process (Astuti et al., 2017; Damanik \& Tanjung, 2013; Siti Hadizah et al., 2021). The identification results obtained that one of the causes of the above problems is that the learning media used by teachers in the physics learning process is not appropriate so that learning has not been able to generate student learning motivation optimally. Teachers can still not develop effective and efficient learning media (Manurung \& Panggabean, 2020; Surata et al., 2020). Teachers have not optimally used ICT learning media, so many students are less interested and do not understand what the teacher has conveyed. As a result, student learning outcomes have not been maximized. Teachers still use limited interactive media in the learning process, resulting in low student learning outcomes (Dasril \& Usmeldi, 2020; Fauyan, 2019).

Based on the causes of the problems above, the solution offered is exciting and interactive learning media in learning physics. Considering that physics is a relatively abstract concept, it is necessary to use ICT media based on Macromedia flash software to facilitate students' absorption of physics material (Viajayani et al., 2013). ICT media can overcome abstract physics learning problems by displaying images in animations and videos (Suseno, 2015). ICT learning media can also make abstract concepts concrete with static visualization and dynamic visualization (Syefrinando, 2016). ICT media is beneficial in facilitating the delivery of abstract messages in the form of an attractive and interactive website. One of the subjects known for its abstract concepts in physics. Physics laws and concepts are abstract, so they become obstacles for teachers in delivering material to students (Astuti et al., 2017; Mufit et al., 2020). Not all physics concepts can be experimented with in the laboratory because they are abstract (Viajayani et al., 2013). Therefore, teachers must develop and use appropriate ICT media so that physics learning in the classroom becomes exciting and provides an accurate and deep understanding.

Building an ICT learning media requires software to increase students' motivation and enthusiasm to learn and understand the physical symptoms of abstract concepts (Changwong et al., 2018; Haryadi \& Pujiastuti, 2020). Making learning media with software applications is expected to increase students' interest and motivation to learn, further affecting student learning outcomes (Kurniawati et al, 2016). Engaging learning media such as flash software can generate interest in learning to improve student learning outcomes (Sakti et al., 2012; Salim et al., 2011). One of the software that can be used to develop ICT-based physics learning media is Macromedia flash software. Macromedia flash software is one of the software that can create digital and interactive learning media. Macromedia Flash is one of the application programs used to design animations widely used today. One of the research results related to Macromedia flash software is applying physics learning media using Macromedia Flash to create interactive multimedia that can improve student learning outcomes (Fakhri \& Bektiarso, 2018; Gómez et al., 2011).

Macromedia Flash is multimedia that can create videos, animations, images, and sounds quickly and effectively (Fakhri \& Bektiarso, 2018). Media development using Macromedia flash software in physics learning makes abstract material concrete, making objects in applications more interactive to attract the attention and interest of students in the learning process. The advantages of using Macromedia flash media include animation, and the resulting images are very consistent and flexible. Image quality is maintained; program emergence time is relatively fast; the resulting interactive program; easy to create animations; can be integrated with several other programs; the final result can be stored in various forms, and can be used to make short films, and presentations (Haeruddin, 2017).

Previous research stated that interactive multimedia is effectively used to facilitate students ' learning (Knoop-van Campen et al., 2020; Prasetyo et al., 2020). Other studies also state that multimedia will increase students' enthusiasm for learning (Indah Septiani et al., 2020; Khan \& Masood, 2015). Other findings also state that learning media in multimedia will improve student learning outcomes (Daniels \& Gierl, 2017; Mayer, 
2012). Previous research studies discussing physics learning media using Macromedia flash software have been widely tested in the classroom and published in ISSN national and sinta accredited journals. Therefore, it is necessary to summarize, compare and analyze the results of these studies. So that they can understand the suitable media in learning physics and better suggestions for future research, based on this, researchers are interested in conducting research using the meta-analysis method with the title "Meta-analysis of physics learning media usinMacromediaia flash software." The purpose of this study was to analyze physics learning media using Macromedia flash software in terms of student learning outcomes based on the type of research method used, level of education, type of media, and material used as content in the media under study.

\section{METHOD}

This study uses a meta-analysis method that examines several research results in similar problems regarding physics learning media using Macromedia flash software in terms of student learning outcomes. Metaanalysis is quantitative because it uses numerical calculations and statistics for practical purposes, namely to compile and extract information from so much data that is not possible with other methods (Fajrin, 2018). The data collection technique for this research is to collect research articles that discuss physics learning media using Macromedia flash software for the last ten years that have been tested in class and published in national journals with ISSN-summarizing research article data in the form of research variables, research objectives, type of research, education level, material and statistical data that can be used. The research sample was taken using a purposive sampling technique, a non-random technique to obtain data or information by the research theme. The sample consists of 21 articles on physics learning media using Macromedia flash software published in 20112020. Articles come from various sources such as national journals with ISSN, sinta accredited national journals, national journals with ISBN, and IOP Publishing, International Conference of Technology and Education. The articles used must have several criteria to be analyzed, namely having variables that can be used to calculate the effect size. The variables are articles with the average post-test and pretest values, standard deviation, the average of the experimental and control groups, the average post-test of the experimental and control groups, and the average pretest, the standard deviation of the experimental and control groups. $\mathrm{T}$ test results, number of experimental and control groups, and correlation values. The use of each variable based on the data contained in the article is adjusted to the effect size formula. The distribution of 21 research subject articles can be seen in Table 1.

Table 1. Distribution of Article Sample

\begin{tabular}{|c|c|c|c|c|}
\hline No & Research & Types of Research & Types of Media & Materials \\
\hline 1 & Damanik \& Tanjung (2013) & Quasi Eksperimen & Animation media & Suhu dan Kalor \\
\hline 2 & Salim et al., (2011) & $\begin{array}{l}\text { Penelitian Tindakan } \\
\text { Kelas }\end{array}$ & Multimedia & Gaya \\
\hline 3 & Ratna \& Dewi (2017) & Quasi Eksperimen & Multimedia & Besaran dan satuan \\
\hline 4 & Sakti et al., (2012) & Quasi Eksperimen & Multimedia & Fluida Statis \\
\hline 5 & Siagian, Y \& Siagian (2017) & Quasi Eksperimen & Animation media & Momentum dan impuls \\
\hline 6 & (Marnita \& Ernawati, 2017) & Quasi Eksperimen & Multimedia & Gerak \\
\hline 7 & $\begin{array}{l}\text { Turnip \& Panggabean, J } \\
\text { (2017) }\end{array}$ & Quasi Eksperimen & Animation media & Momentum dan impuls \\
\hline 8 & Tampubolon et al. (2020) & Quasi Eksperimen & Animation media & Fluida Statis \\
\hline 9 & $\begin{array}{c}\text { Anggereni \& } \\
\text { Khairurradzikin (2016) }\end{array}$ & Quasi Eksperimen & Animation media & Hukum Newton \\
\hline 10 & Ika, Y (2018) & Quasi Eksperimen & Animation media & Listrik Dinamis \\
\hline 11 & Nopianti et al. (2019) & Quasi Eksperimen & Animation media & Cahaya \\
\hline 12 & Sare, Y \& Budhi (2018) & Quasi Eksperimen & Animation media & Gerak \\
\hline 13 & Siregar et al. (2019) & Quasi Eksperimen & Animation media & Fluida Statis \\
\hline 14 & Abbas, M, L (2019) & Quasi Eksperimen & Animation media & Tekanan \\
\hline 15 & Fartina et al. (2019) & $\begin{array}{l}\text { Research and } \\
\text { Develompent }\end{array}$ & Animation media & Gerak Lurus \\
\hline 16 & Fakhri \& Bektiarso (2018) & True Eksperimen & Animation media & $\begin{array}{c}\text { Momentum Impuls dan } \\
\text { Tumbukan }\end{array}$ \\
\hline 17 & (Saputra \& Sari, 2018) & $\begin{array}{l}\text { Pre-eksperimental } \\
\text { design }\end{array}$ & Animation media & Tekanan \\
\hline 18 & Elfina, Maria, \& Flash & Pre-eksperimental & Learning Media & Tekanan Zat Cair \\
\hline
\end{tabular}




\begin{tabular}{cclcl}
\hline No & Research & Types of Research & Types of Media & Materials \\
\hline \multirow{2}{*}{ (2017) } & design & & \\
& Sastria et al. (2013) & $\begin{array}{l}\text { Pre-eksperimental } \\
\text { design }\end{array}$ & Learning Media & Pengukuran \\
20 & Thahir et al. (2019) & Quasi Eksperimen & $\begin{array}{c}\text { Animation media } \\
\text { Learning Media }\end{array}$ & $\begin{array}{l}\text { Suhu dan Panas } \\
\text { Quasi Eksperimen }\end{array}$ \\
\hline
\end{tabular}

The steps of data analysis are; (1) identify the type of research and the research variables that have been found, are included in the appropriate variable column, (2) identify the mean and standard deviation of the experimental group data/before treatment and control group/after treatment for each subject/sub-study that trials have been carried out, (3) identify t-tests for each subject/sub research that have been tested, (4) calculate effect size (ES) using statistical parameters, (5) analyze effect size (ES) from the results of collecting research articles, and (6) conclude the results of data analysis. After the effect size is calculated based on the appropriate formula, then the effect size is categorized by the effect size criteria according to Diancer in Table 2.

Table 2. Criteria for Effect Size (ES)

\begin{tabular}{ccc}
\hline No & ES & Category \\
\hline 1 & ES $\leq 0,15$ & Very low \\
2 & $0,15<\mathrm{ES} \leq 0,40$ & low \\
3 & $0,40<\mathrm{ES} \leq 0,75$ & Currently \\
4 & $0,75<\mathrm{ES} \leq 1,10$ & High \\
5 & $\mathrm{ES}>1,10$ & Very high \\
\hline
\end{tabular}

(Olejnik \& Algina, 2003)

\section{RESULT AND DISCUSSION}

The first result of this research is the type of research that has been done by previous researchers in the development of physics learning media using Macromedia flash software. Based on data analysis, it was found that $71 \%$ of articles on physics learning media used Macromedia flash software using a quasiexperimental method. The research that has been entered as a journal article is quasi-experimental research that tests the effectiveness of physics learning media using Macromedia flash software in terms of student learning outcomes. In addition, $14 \%$ of the research is a pre-experimental design research that tests the effectiveness of physics learning media. The rest are actual experiments, R \& D as much as 5\%, and PTK as much as $5 \%$.

Research on physics learning media using Macromedia flash software uses more quasi-experimental methods because this method can analyze the effectiveness of physics learning media using Macromedia flash software in terms of student learning outcomes (Gunawam et al., 2015). In addition, this method can assess the effect of an action on behavior or test whether there is an effect of the action. The action in the experiment is called treatment which means giving conditions that will be assessed for their effect pengaruhnya (Gunawam et al., 2015; Umam \& Yudi, 2016). This treatment is given in the form of learning media using Macromedia flash software. This is in line with previous research, which determined how much influence the problembased learning model assisted by Macromedia flash had on student learning outcomes on the subject matter of static fluids in the X-MIA class of MAN Binjai (Sulani et al., 2020). The research he conducted using a quasiexperimental method showed that student learning outcomes were classified as very good, with an average of 81.87. The results of this study provide input to the next researcher to research physics learning media with a quasi-experimental method with better testing. The results of these two studies are the effect size (ES) of physics learning media using Macromedia flash software in terms of student learning outcomes based on the level of education presented in table 3 .

Table Three shows that research on physics learning media using Macromedia flash software in terms of student learning outcomes is mainly carried out at the SMA/MA level, namely 57\%, followed by research at the SMP/MTs level as much as $24 \%$, followed by research at the SMK level as much as $9.5 \%$, and research at the university level as much as $9.5 \%$. The results of the analysis of the effect size of physics learning media using Macromedia flash software in terms of physics learning outcomes based on education level found that the effect size was very high in universities with an average value of 2.79. The effect size is high at the junior high school level, with an average value of 0.89. The effect size is moderate at the SMA and SMK levels, with an average value of 0.74 and 0.45 , respectively. This shows that physics learning media using Macromedia flash software is effective in improving student learning outcomes at the level of junior high school and equivalent, high school equivalent, vocational school, and university. 
Table 3. Distribution of Education Levels

\begin{tabular}{llcccc}
\hline No. & Education Level & Frekuensi & $\begin{array}{c}\text { Frequency Relative } \\
\text { Frequency(\%) }\end{array}$ & ES & Category \\
\hline 1 & SMP/MTs & 5 & 24 & 0.89 & high \\
2 & SMA/MAN & 12 & 57 & 0.74 & Currently \\
3 & SMK & 2 & 9.5 & 0.45 & Currently \\
4 & PerguruanTinggi & 2 & 9.5 & 2.79 & Very high \\
& (PT) & & & \\
\hline
\end{tabular}

Physics learning media using Macromedia flash software in universities can improve students' understanding of concepts. This is in line with previous research on physics learning using Macromedia flashMX animation media and images to improve students' understanding of concepts (Yuliani, 2017). The results of his research show that there is an increase in understanding of concepts in quantum physics learning by using Macromedia Flash - MX animation media. This is because physics learning media using Macromedia flash software in universities can stimulate students' thoughts, feelings, interests, and attention in such a way that the learning process can be more optimal and students can learn independently (Gunawan et al., 2015; Usmeldi, 2012). Physics learning media using Macromedia flash software can visualize abstract material into concrete so that it can help students understand physics learning material in universities (Viajayani, et all, 2013; Yuliani, 2017).

Based on the description above, the results of this study indicate that physics learning media using Macromedia flash software at the higher education level (PT) is effectively used. Research on physics learning media using Macromedia flash software at the education level of SMA, SMK, and SMP/MTs, needs to do a more in-depth needs analysis so that the media used is genuinely compelling. The results of these three studies are the effect size (ES) of physics learning media using Macromedia flash software in terms of student learning outcomes based on the type of media developed, which is presented in table 4 .

Table 4. Distribution of Media Types

\begin{tabular}{cccccc}
\hline No & Media Type & Frequency & Relative Frequency (\%) & ES & Category \\
\hline 1 & Animation Media & 14 & 67 & 0,77 & High \\
2 & Multimedia & 4 & 19 & 1,98 & Very high \\
3 & Learning Media & 3 & 14 & 0,69 & Currently \\
\hline
\end{tabular}

Based on table 4, the average effect size of the media types from the articles analyzed consists of the medium, high, and very high categories. The type of learning media is in the medium category with an average effect size of 0.69 , the type of animation media is in the high category with an average effect size of 0.77 , while the type of multimedia media is in the very high category with an average effect size of 1.98 . . This proves that physics learning media using Macromedia flash software in terms of physics learning outcomes has a significant effect. This is because physics learning media using Macromedia flash software can increase student activity during learning. As was done by researchers in their research to determine how much influence the discovery learning model assisted by Macromedia flash animation media on the activities of students on pressure material at SMP N 1 Suhaid, obtained an effect size of 1.19 in the very high category. His research shows that the activities of students during learning are classified as very good with a percentage of 95\% - 100\% (Saputra, 2018). This is because using Macromedia flash animation media can improve the quality of learning, both students' learning motivation, student learning outcomes, or teaching activities in the classroom (Margareta \& Wahyuno, 2014; Handhika J, 2012; Siagian, Y, \& Siagian, H, 2017). It can also increase the curiosity of students and stimulate students to react physically and emotionally.

The type of multimedia using Macromedia flash software has a very high influence on student learning outcomes, with an average effect size of 1.98. This is because using multimedia using Macromedia flash software can remediate students' misconceptions. Previous research also used spreadsheet-assisted Macromedia flash, one of the computer-assisted instruction learning media, to perform simulations in learning. This study obtained an effect size of 1.2 in the very high category (Elfina, Maria, \& Hamdani, 2017). Using Macromedia flash in Elfina's research can help students see abstract concepts that look like actual processes. Students can manipulate data, collect, analyze data, and draw conclusions through the simulation because Macromedia flash can visualize abstract concepts. The advantage of Macromedia Flash is that it can create animations, presentations, and simulations from one form to another, which is then moved by following a predetermined path (Fitria et al., 2016; Siagian \& Simatupang, 2017). Simulation results that are contrary to students' initial ideas, if carried out repeatedly, will eventually result in a change in the concept of students (Paul, 2013). The results of 
these four studies are the effect size (ES) of physics learning media using macromedia flash software in terms of student learning outcomes based on the learning materials presented in table 5 .

Table 5. Material Distribution

\begin{tabular}{cccccc}
\hline No & Material & Frequency & Relative Frequency (\%) & ES & Category \\
\hline 1 & Suhu dan kalor & 2 & 9.52 & 0,74 & Currently \\
2 & Gaya & 1 & 4.76 & 0,35 & Low \\
3 & Besaran dan satuan & 1 & 4.76 & 0,99 & high \\
4 & Momentum dan & 3 & 14.3 & 0,51 & Currently \\
& impuls & & & \\
5 & Fluida statis & 3 & 14.3 & 0,90 & high \\
6 & Hukum newton & 1 & 4.76 & 1,3 & Sangat Tinggi \\
7 & Listrik dinamis & 1 & 4.76 & 0,50 & Currently \\
8 & Gerak & 2 & 9.52 & 3,82 & Sangat Tinggi \\
9 & Gerak lurus & 1 & 4.76 & 0,13 & Very Low \\
10 & Tekanan & 2 & 9.52 & 0,90 & high \\
11 & Tekanan zat cair & 1 & 4.76 & 1,20 & Very high \\
12 & Pengukuran & 1 & 4.76 & 0,74 & Currently \\
13 & Cahaya & 1 & 4.76 & 0.20 & Low \\
14 & Medan Magnet & 1 & 4.76 & 0.13 & Very Low \\
\hline
\end{tabular}

The analyzed media types were 14 topics of learning material, as shown in Table 7 above. Based on the data obtained, the average effect size value is in the very low to very high category. The physics materials that fall into the very low category are straight motion and magnetic fields; low category, style, and light material. Furthermore, that are included in the medium category are temperature and heat, momentum and impulse, dynamic electricity, and measurement. Then the materials whose effect size is in the high category are quantities and units, static fluid, and pressure. Effect size in the very high category is Newton's law of motion and the pressure of liquids. The highest effect size is shown in multimedia with motion material, which is 3.82 .

This type of multimedia media makes it easy for students to learn individually or in groups, makes it easy for teachers to deliver material, increases students' motivation and learning outcomes (Sunarti \& Anggraini, 2013; Faizah, et all, 2020). Multimedia can reduce the saturation of students because the learning process is carried out by most students interactively (Abendroth \& Richter, 2021; Choi et al., 2019). Based on the description above, it can be concluded that multimedia is the most effective learning media. Multimedia can then be developed in multimedia to increase students' motivation and critical thinking skills (Rante, et all, 2013; Marnita \& Ermawati, 2017). Research on physics learning media using Macromedia flash software on the types of learning media and animation media needs to do a more in-depth analysis of needs so that the media used is genuinely effective.

Physics learning media using Macromedia flash software with motion material is developed in the form of learning media that makes it easier for students to master concepts and assist educators in communicating with students and even able to package material to be more explicit, complete, and interesting for students (Saputra \& Sari, 2018, Martina \& Ernawati, 2017). The process of learning physics focuses on concepts and the relationship between abstract concepts. The characteristics of some abstract concepts in physics cause difficulties in visualizing and conveying concepts to students (Gunawan et al., 2015; Tampubolon, et all, 2020). This difficulty is then overcome by using physics learning media (Lia, 2015). So that learning media become teaching aids that can motivate students to be creative and construct their knowledge and concrete abstract concepts (Handhika, 2012; Rante et al., 2013).

\section{CONCLUSION}

The best effectiveness of physics learning media using Macromedia flash software in terms of student learning outcomes based on education level is in Higher Education. The best effectiveness of physics learning media using Macromedia flash software in terms of student learning outcomes based on the type of media developed is multimedia. The best effectiveness of physics learning media using Macromedia flash software in terms of student learning outcomes based on learning material is motion material. It can be concluded that learning media using Macromedia flash software is a medium that can help students in learning. 


\section{REFERENCES}

Abbas, M, L, H. (2019). Penerapan Animasi Macromedia Flash Untuk Meningkatkan Hasil Belajar Fisika Pada Materi Tekanan. Ed-Humanistics, 4(1), 509-515. https://doi.org/10.33752/ed-humanistics.v4i1.359.

Abendroth, J., \& Richter, T. (2021). How to understand what you don't believe: Metacognitive training prevents belief-biases in multiple text comprehension. Learning and Instruction, 71(August 2020), 101394. https://doi.org/10.1016/j.learninstruc.2020.101394.

Anggereni, S., \& Khairurradzikin. (2016). Efektivitas Pembelajaran Menggunakan Media Pembelajaran Macromedia Flash dalam meningkatkan pemahaman konsep Fisika Materi Hukum Newton. Jurnal Biotek, 4(2), 333-350. https://doi.org/10.24252/jb.v4i2.1890.

Anwariningsih, \& Ernawati. (2013). Development of Interactive Media for ICT Learning at Elementary School based on Student Self Learning. Journal of Education and Learning, 7(2), 121-128. https://doi.org/10.11591/edulearn.v7i2.226.

Ariani, T. (2020). Analysis of Students' Critical Thinking Skills in Physics Problems. Physics Educational Journal, 3(1), 1-13. https://doi.org/10.37891/kpej.v3i1.119.

Arrosagaray, M., González-Peiteado, M., Pino-Juste, M., \& Rodríguez-López, B. (2019). A comparative study of Spanish adult students' attitudes to ICT in classroom, blended and distance language learning modes. Computers and Education, 134(October 2018), 31-40. https://doi.org/10.1016/j.compedu.2019.01.016.

Astuti, I. A. D., Sumarni, R. A., \& Saraswati, D. L. (2017). Pengembangan Media Pembelajaran Fisika Mobile Learning Berbasis Android. JRPK: Jurnal Riset Pendidikan Kimia, 7(2), 160-167. https://doi.org/10.21009/jrpk.072.10.

Baya'a, N., Daher, W., \& Anabousy, A. (2019). The development of in-service mathematics teachers' integration of ICT in a community of practice: Teaching-in-context theory. International Journal of Emerging Technologies in Learning, 14(1), 125-139. https://doi.org/10.3991/ijet.v14i01.9134.

Changwong, K., Sukkamart, A., \& Sisan, B. (2018). Critical thinking skill development: Analysis of a new learning management model for Thai high schools. Journal of International Studies, 11(2), 37-48. https://doi.org/10.14254/2071.

Chin, K.-Y., \& Wang, C.-S. (2021). Effects of augmented reality technology in a mobile touring system on university students' learning performance and interest. Australasian Journal of Educational Technology, 37(1). https://doi.org/10.14742/ajet.5841.

Choi, S. J., Jeong, J. C., \& Kim, S. N. (2019). Impact of vocational education and training on adult skills and employment: An applied multilevel analysis. International Journal of Educational Development, 66(12), 129-138. https://doi.org/10.1016/j.ijedudev.2018.09.007.

Damanik, R., \& Tanjung, R. (2013). Pengaruh Media Pembelajaran Animasi Macromedia Flash Terhadap Hasil Belajar Siswa di Kelas X Man Lima Puluh. Inovasi Pembelajaran Fisika Unimed, 1(2). https://doi.org/https://doi.org/10.24114/inpafi.v1i2.2017.

Daniels, L. M., \& Gierl, M. J. (2017). The impact of immediate test score reporting on university students' achievement emotions in the context of computer-based multiple-choice exams. Learning and Instruction, 52. https://doi.org/10.1016/j.learninstruc.2017.04.001.

Dasril, \& Usmeldi. (2020). Pengembangan E-Media Pembelajaran Interaktif berbasis Problem Solving pada Mata Pelajaran Dasar Listrik dan Elektronika. Jurnal Pendidikan Teknik Elektro, 01(01), 58-61.

Elfina, N., Maria, H. T., \& Flash, M. (2017). Penggunaan macromedia flash berbantuan spreadsheet untuk meremediasi miskonsepsi pada tekanan zat cair di SMP. Jurnal Pendidikan Dan Pembelajaran Khatulistiwa, 6(5), 1-17. https://jurnal.untan.ac.id/index.php/jpdpb/article/view/19943.

Elfina, N., Maria, H. T., \& Hamdani. (2017). Penggunaan Macromedia Flash Berbantuan Spreadsheet Untuk Meremediasi Miskonsepsi Pada Tekanan Zat Cair Di SMP. Jurnal Pendidikan Dan Pembelajaran Khatulistiwa, 6(5). https://jurnal.untan.ac.id/index.php/jpdpb/article/view/19943.

Fajrin, O. A. (2018). Pengaruh Model Talking Stick terhadap Hasil Belajar IPS Siswa SD. Jurnal Bidang Pendidikan Dasar. https://doi.org/10.21067/jbpd.v2i1a.2353.

Fakhri, M. I., \& Bektiarso, S. (2018). Penggunaan Media Pembelajaran Animasi Berbantuan Macromedia Flash Pada Pembelajaran Fisika Pokok Bahasan Momentum , Impuls , Dan Tumbukan Kelas X SMA. 271277. https://doi.org/https://doi.org/10.19184/jpf.v7i3.8599.

Fartina, Hizbi, T., \& Syahidi, K. (2019). Development of Interactive Physics Learning Media Macromedia Flash 8 Based on Straight Motion Material. Journal of Physics: Conference Series, 1539(1). https://doi.org/10.1088/1742-6596/1539/1/012023.

Fauyan, M. (2019). Developing Interactive Multimedia Through Ispring on Indonesian Learning with the Insight Islamic Values in Madrasah Ibtidaiyah. Al Ibtida: Journal Pendidikan Guru MI, 6(2). https://doi.org/10.24235/al.ibtida.snj.v6i2.4173.

Fitria, Priatmoko, S., \& Kasmui. (2016). Penggunaan Multimedia Interaktif Dalam Meminimalisasi Miskonsepsi 
Siswa Pada Materi Pokok Larutan Penyangga. Jurnal Inovasi Pendidikan Kimia, 10(1), 1641-1650. https://journal.unnes.ac.id/nju/index.php/JIPK/article/view/6010.

Gómez, E., Maresca, P., Caja, J., Barajas, C., \& Berzal, M. (2011). Developing a new interactive simulation environment with Macromedia Director for teaching applied dimensional metrology. Measurement, 44(9). https://doi.org/10.1016/j.measurement.2011.07.004.

Gunawam, G., Harjono, A., \& Sutrio, S. (2015). Multimedia Interaktif dalam Pembelajaran Konsep Listrik Bagi Calon Guru. Jurnal Pendidikan Fisika Dan Teknologi, 1(1), 9-14. https://doi.org/http://dx.doi.org/10.29303/jpft.v1i1.230.

Gunawan, G., Sahidu, H., Harjono, A., \& Suranti, N. M. Y. (2017). The effect of project based learning with virtual media assistance on student's creativity in physics. Jurnal Cakrawala Pendidikan, 2. https://doi.org/10.21831/cp.v36i2.13514.

Handhika, J. (2012). Efektivitas media pembelajaran im3 ditinjau dari motivasi belajar. Jurnal Pendidikan IPA Indonesia, 1(2), 109-114. https://doi.org/10.15294/jpii.v1i2.2127.

Haryadi, R., \& Pujiastuti, H. (2020). PhET simulation software-based learning to improve science process skills. Journal of Physics: Conference Series, 1521(2). https://doi.org/10.1088/1742-6596/1521/2/022017.

Heemskerk, I., Volman, M., Admiraal, W., \& Ten Dam, G. (2012). Inclusiveness of ICT in secondary education: Students appreciation of ICT tools. International Journal of Inclusive Education, 16(2), 155-170. https://doi.org/10.1080/13603111003674560.

Ika, Y, E. (2018). Penerapan Macromedia Flash untuk Meningkatkan Pemahaman Konsep Fisika Siswa di SMA. $\begin{array}{llll}\text { Scientifical Colloquia, } & \text { l(September), } & 31-36 . & \mathrm{http}: / / \mathrm{e}-\end{array}$ journal.uniflor.ac.id/index.php/jupika/article/view/582.

Indah Septiani, A. nisa N. S., Septiani, I., Rejekiningsih, T., Triyanto, \& Rusnaini. (2020). Development of interactive multimedia learning courseware to strengthen students' character. European Journal of Educational Research, 9(3), 1267-1279. https://doi.org/10.12973/eu-jer.9.3.1267.

Khan, F. M. A., \& Masood, M. (2015). The Effectiveness of an Interactive Multimedia Courseware with Cooperative Mastery Approach in Enhancing Higher Order Thinking Skills in Learning Cellular Respiration. Procedia - Social and Behavioral Sciences, 176, 977-984. https://doi.org/10.1016/j.sbspro.2015.01.567.

Kim, M., Lee, H., \& Kwak, J. (2020). The changing patterns of China's international standardization in ICT under techno-nationalism: A reflection through 5G standardization. International Journal of Information Management, 54. https://doi.org/https://doi.org/10.1016/j.ijinfomgt.2020.102145.

Knoop-van Campen, C. A. N., Segers, E., \& Verhoeven, L. (2020). Effects of audio support on multimedia learning processes and outcomes in students with dyslexia. Computers and Education, 150(February), 103858. https://doi.org/10.1016/j.compedu.2020.103858.

Lange, S., Pohl, J., \& Santarius, T. (2020). Digitalization and energy consumption. Does ICT reduce energy demand? Ecological Economics, 176. https://doi.org/10.1016/j.ecolecon.2020.106760.

Lawrence, J. E., \& Tar, U. A. (2018). Factors that influence teachers' adoption and integration of ICT in teaching/learning process. Educational Media International, 55(1), 79-105. https://doi.org/10.1080/09523987.2018.1439712.

Lia, L. (2015). Multimedia Interaktif Sebagai Salah Satu Alternatif Pembelajaran dalam Bidang Pendidikan Sains. Jurnal Inovasi Dan Pembelajaran Fisika, 2(2), 132-140. https://doi.org/https://doi.org/10.36706/jipf.v2i2.2614.

Manurung, \& Panggabean. (2020). Improving Students' Thinking Ability In Physics Using Interactive Multimedia Based Problem Solving. Cakrawala Pendidikan, 39(2), 460-470. https://doi.org/10.21831/cp.v39i2.28205.

Margareta, L., \& Wahyuno, E. (2014). Penggunaan Media Animasi Macromedia Flash Untuk Meningkatkan Kualitas Pembelajaran Ipa Siswa Tunarungu Kelas II SDLB. Jurnal P3Lb, 1(2), 137-139. https://doi.org/10.17977/um029v1i22014p137-139.

Marnita, \& Ernawati. (2017). The Use of Interactive Multimedia (Macromedia Flash) to Increase Creative Thinking Ability of Students in Basic Physics Subject. Jurnal Pendidikan Fisika Indonesia, 13(2), 7178. https://doi.org/10.15294/jpfi.v13i2.10152.

Mayer, R. E. (2012). A Cognitive Theory of Multimedia Learning. Multimedia Learning, July, 41-62. https://doi.org/10.1017/cbo9781139164603.004.

Mufit, F., Asrizal, Hanum, S. ., \& Fadhilah, A. (2020). Preliminary research in the development of physics teaching materials that integrate new literacy and disaster literacy Preliminary research in the development of physics teaching materials that integrate new literacy and disaster literacy. The 2nd International Conference on Research and Learning of Physics, 0-12. https://doi.org/10.1088/17426596/1481/1/012041.

Nopianti, G., Aji, S, D., \& Hudha, M, N. (2019). Metode Eksperimen Menggunakan Macromedia Flash 
Terhadap Minat dan Prestasi Belajar Fisika. Seminar Nasional Pendidikan Fisika, 1-7. http://prosiding.unipma.ac.id/index.php/SNPF/article/view/1385.

Nursamsu, N., \& Kusnafizal, T. (2017). Pemanfaatan Media Pembelajaran Ict Sebagai Kegiatan Pembelajaran Siswa Di Smp Negeri Aceh Tamiang. Jurnal IPA \& Pembelajaran IPA, 1(2), 165-170. https://doi.org/10.24815/jipi.v1i2.9691.

Olejnik, S., \& Algina, J. (2003). Generalized Eta and Omega Squared Statistics: Measures of Effect Size for Some Common Research Designs. Psychological Methods, 8(4).

Prasetyo, G., Hidayatullah, M. F., Akhyar, M., Wiranto, \& Perdana, R. (2020). Strengthening Students' Character Through Multimedia Learning In Primary Schools Education: Systematic LiteraturPrasetyo, G., Hidayatullah, M. F., Akhyar, M., Wiranto, \& Perdana, R. (2020). Strengthening Students' Character Through Multimedia Learning In . Humanities \& Social Sciences Reviews, 8(3), 268-277. https://doi.org/10.18510/hssr.2020.8328.

Putri, I, P., \& Sibuca, A, M. (2014). Pengembangan Media Pembelajaran Interaktif Pada Mata Pelajaran Fisika. Jurnal Teknologi Informasi \& Komunikasi Dalam Pendidikan, 1(2), 145-155. https://doi.org/https://doi.org/10.24114/jtikp.v1i2.1876.

Rajagukguk, \& Simanjuntak. (2015). Problem-Based Mathematics Teaching Kitsintegrated With ICT To Improvestudents' Critical Thinking Ability Injunior High Schools In Medan. Cakrawala Pendidikan, 34(3). https://doi.org/10.21831/cp.v3i3.7342.

Rante, P., Sudarto, \& Ihsan, N. (2013). Pengembangan multimedia pembelajaran fisika berbasis audio-video eksperimen listrik dinamis di smp. Jurnal Pendidikan IPA Indonesia, 2(2), 203-208. https://doi.org/10.15294/jpii.v2i2.2724.

Rozi, F., \& Kristari, A. (2020). Pengembangan Media Pembelajaran Game Edukasi Berbasis Android Pada Mata Pelajaran Fisika Untuk Siswa Kelas Xi Di Sman 1 Tulungagung. JIPI (Jurnal Ilmiah Penelitian Dan Pembelajaran Informatika), 5(1), 35-44. https://doi.org/10.29100/jipi.v5i1.1561.

Sakti, I., Puspasari, Y. M., \& Risdianto, E. (2012). Pengaruh model pembalajaran langsung (Direct Instruction) Melalui Media Animasi Berbasis Macromedia Flash Terhadap Minat Belajar dan Pemahaman Konsep Fisika Siswa di SMA Plus Negeri 7 Kota Bengkulu. Jurnal Exacta, X(1), 1-10.

Salim, A., Ishafit, \& Toifur, M. (2011). Pemanfaatan Media Pembelajaran (Macromedia Flassh) dengan Pendekatan Kontruktivis dalam Meningkatkan Efektivitas Pembelajaran Fisika Pada Konsep Gaya. Prosiding Seminar Nasional Penelitian, Pendidikan, Dan Penerapan MIPA.F-279, 453-462. https://doi.org/10.31571/jpsa.v1i1.899.

Saprudin, S., Liliasari, L., Setiawan, A., \& Prihatmanto, A. (2020). Optical Gamification (OG); Serial Versus Random Model to Improve Pre-Service Physics Teachers' Concept Mastery. International Journal of Emerging Technologies in Learning (IJET), 15(9), 39-59. https://doi.org/https://doi.org/10.3991/ijet.v15i09.11779.

Saputra, W., \& Sari, I. N. (2018). Pengaruh Model Discovery Learning Berbantuan Media Animasi Macromedia Flash terhadap Aktivitas Siswa pada Materi Tekanan di SMP Negeri 1 Suhaid. Jurnal Pendidikan Sains Dan Aplikasinya (JPSA), 1(1), 17-21.

Sare, Y, G., \& Budhi, W. (2018). Pengaruh Media Macromedia Flash Terhadap Prestasi Belajar Fisika. Jurnal Ilmiah Pendidikan Fisika-COMPTON, 5(1), 37-42. https://doi.org/10.24114/inpafi.v1i2.2017.

Sastria, A., Sahala, S., \& Maria, H, T. (2013). Remediating Students' Mistakes in Using Caliders Throught Direct Instruction Combined with Macromedia Flash. Jurnal Pendidikan Dan Pembelajaran Khatulistiwa, 2(9), 1-9.

Septia, T., Prahmana, R. C. I., Pebrianto, \& Wahyu, R. (2018). Improving students spatial reasoning with course lab. Journal on Mathematics Education, 9(2), 327-336. https://doi.org/10.22342/jme.9.2.3462.327-336.

Siagian, Y, Y., \& Siagian, H. (2017). Pengaruh Model Pembelajaran Inkuiry Training Berbantuan Macromedia Flash Terhadap Hasil Belajar Siswa. Jurnal Inovasi Pembelajaran Fisika, 1(1), 7-16. https://doi.org/10.24114/inpafi.v5i3.9129.

Siagian, H., \& Simatupang, R. (2017). Pengaruh Model Pembelajaran Inkuiri Terbimbing Terintegrasi Animasi Flash Terhadap Hasil Belajar Siswa Pada Materi Pokok Fluida Dinamis. Jurnal Penelitian Bidang Pendidikan, 23(1), 47-54. https://doi.org/10.24114/jpp.v23i1.10000.

Siregar, J., Novika, S., Dewi, R. M., Muslim, U., Al, N., Muslim, U., Al, N., Garu, J., No, I. I., \& Medan, K. (2019). Pengaruh Model Belajar Demonstrasi Menggunakan Macromedia Flash Dalam Belajar Fisika Bagi Siswa SMA. Prossiding Seminar Hasil Penelitian, 241-245. https://eprosiding.umnaw.ac.id/index.php/penelitian/article/view/542.

Siti Hadizah, S., Aulia, J., \& Rahmawati. (2021). Pengaruh Media Animasi Berbasis Macromedia Flash terhadap Kemampuan Siswa Dalam Pembelajaran Fisika Hukum Archimedes di SMP/MTs. Journal for Teachers and Learning, 1(2), 24-38. https://ejournal.anotero.org/index.php/milenial/article/view/38.

Sulani, Y. B. D., Tampubolon, T., \& Sembiring, E. B. (2020). Pengaruh Model Problem Based Learning 
Berbantu Macromedia Flash Terhadap Hasil Belajar Siswa Pada Materi Pokok Fluida Statis Di Kelas X-Mia Semester Ii Man Binjai. Inovasi Pembelajaran Fisika, 8(1). https://doi.org/10.24114/inpafi.v8i1.17598.

Sunarti, \& Anggraini, D. (2013). Pengembangan Bank Soal Dan Pembahasan Ujian Nasional Berbasis Multimedia Pembelajaran Interaktif Dengan Macromedia Authorware 7.0. Jurnal Cakrawala Pendidikan, 3, 394-408. https://doi.org/10.21831/cp.v0i3.1138.

Surata, I. K., Sudiana, I. M., \& Sudirgayasa, I. G. (2020). Meta-Analisis Media Pembelajaran pada Pembelajaran Biologi. Journal of Education Technology, 22 4(1), https://doi.org/http://dx.doi.org/10.23887/jet.v4i1.24079.

Suseno, H. (2015). Pengembanganmultimedia With Concept Maps (Mmcmaps) Mata Pelajaran Fisika Untuk Meningkatkan Prestasi Belajar Siswa SMA. Jurnal Pendidikan Fisika Dan Keilmuan (JPFK), 1(2), 99. https://doi.org/10.25273/jpfk.v1i2.18.

Syefrinando, B. (2016). Pengembangan Media Pembelajaran Berbasis Macromedia Flash Professional 8. 1(2), 102-106. https://doi.org/http://dx.doi.org/10.30631/ijer.v1i2.21.

Tampubolon, T., Selani, Y, B, D., \& Sembiring, E, B. (2020). Pengaruh Model Problem Based Learning Berbantuan Macromedia Flash Terhadap Hasil Belajar Siswa Pada Materi Pokok Fluida Statis Di Kelas X-MIA Semester II Man Binjai. Jurnal Inovasi Pembelajaran Fisika, 8(1), 77-83. https://doi.org/10.24114/inpafi.v8i1.17598.

Thahir, A., Diani, R., \& Permana, D. (2019). Advance Organizer Model in Physics Learning: Effect Size Test on Learning Activities and Students' Conceptual understanding. Journal of Physics: Conference Series, 1467(1), 0-13. https://doi.org/10.1088/1742-6596/1467/1/012076.

Turnip, A., \& Panggabean, J, H. (2017). Pengaruh Model Pembelajaran Teams Games Tournament (TGT) Berbantuan Macromedia Flash Terhadap Hasil Belajar Siswa Pada Materi Pokok Momentum dan Impuls Kelas X Semester II Di SMA Negeri 15 Medan T.A. Jurnal Inovasi Pembelajaran Fisika, 1(1), 7-16. https://doi.org/10.24114/inpafi.v8i1.17598.

Umam, K., \& Yudi. (2016). Pengaruh Menggunakan Software Macromedia Flash 8 Terhadap Hasil Belajar Matematika Siswa Kelas VIII. Jurnal Pendidikan Matematika, $1(1), \quad 84$. https://doi.org/10.22236/kalamatika.vol1no1.2016pp84-92.

Usmeldi. (2012). Efektivitas Macromedia Flash Interaktif. Seminar Nasional Fisika, 111-115. http://journal.unj.ac.id/unj/index.php/prosidingsnf/article/view/6163.

Viajayani, E. R., Rdiyono, Y., \& Raharjo, D. T. (2013). Pengembangan Media Pembelajaran Fisika Menggunakan Macromedia Flash Pro 8 Pada Pokok Bahasan Suhu dan Kalor. Jurnal Pendidikan Fisika, 1(1), 144-155. https://jurnal.fkip.uns.ac.id/index.php/pfisika/article/view/1774.

Yuliani, H. (2017). Pembelajaran Fisika menggunakan Media Animasi Macromedia Flash-MX dan Gambar untuk Meningkatkan Pemahaman Konsep Mahasiswa. Jurnal Ilmiah Pendidikan Fisika Al-Biruni, 6(1), 13-21. https://doi.org/10.24042/jpifalbiruni.v6i1.596. 